\title{
Clinical research of cervical non-carious lesion restoration
}

\author{
Slavoljub Živković, Srđan Županjac, Sonja Stojičić, Jelena Nešković, Dragica Manojlović \\ Klinika za Bolesti zuba, Stomatološki fakultet Beograd \\ Dept. of Conservative Dentistry and Endodontics, School of Dentistry Belgrade
}

\author{
ORIGINALNI RAD (OR) \\ ORIGINAL ARTICLE
}

\begin{abstract}
KRATAK SADRŽAJ
Terapija nekarijesnih cervikalnih lezija je značajan problem u restaurativnoj stomatologiji, zbog nejasne etiologije, kliničke dijagnoze ali i izbora restaurativne procedure.

Cilj: Cilj ovog rada je bio da se klinički proveri efikasnost restauracija nekarijesnih cervikalnih lezija zuba u zavisnosti od korišćenih materijala za restaurativne ispune. Materijal i metod: Klinička ispitivanja su obuhvatila 62 zuba različitih morfoloških grupa kod pacijenata oba pola $i$ različite starosti. Restauracija gingivalnih lezija, bez prethodne preparacije, uradena je kompozitnim adhezivnim sistemom SINGLE BOND / Valux Plus (3M) (30 zuba) i kompomerom DYRACT AP (Dentsplay) (32 zuba). Ispuni su procenjivani na kontrolnim pregledima posle 3, 6 i 12 meseci primenom modifikovanih kriterijuma po Ridge-u i Cvar-u.
\end{abstract}

Rezultati: Dobijeni rezultati su pokazali da posle 3 i 6 meseci nije bilo promena na ispunima ni kod jednog ispitivanog parametra i svi ispuni su ocenjeni maksimalnom ocenom A. Posle 12 meseci, u dva slučaja ispunjenih kompozitima, ivična adaptacija je ocenjena ocenom $B(6,7 \%)$. Ivična adaptacija je i u dva zuba restaurisanih kompomerima ocenjena ocenom B (6,3\%). Pojava postoperativne osetljivosti, ivične diskoloracije i sekundarnog karijesa nije registovana ni u jednom slučaju posle observacionog perioda od 12 meseci.

Zaključak: Za restauraciju nekarijesnih cervikalnih lezija mogu se koristiti kompozitni materijali sa odgovarajućim adhezivnim sistemima i novije generacije kompomera.

Ključne reči: Nekarijesne cervikaIne lezije, kompoziti, kompomeri

\section{SUMMARY}

The therapy of non-caries cervical lesions is an important problem in restorative dentistry, for the ambiguous aetiology, clinical diagnoses and for the selection of restorative procedure.

Aim: The aim of this work was to clinically check the efficiency of non-caries cervical lesions restoration depending on materials used for restorative fillings. Materials and methods: Clinical researches covered 62 teeth of different morphology group at the patients of both gender and of different age. The restoration of gingival lesions, with no previous preparation, was done with composite adhesive system SINGLE BOND/Valux Plus (3M) (30 teeth) and with campomer DYRACT AO (Dentsplay) (32 teeth). The fillings were estimated on the checkups which took place on 3,6 and12 months applying modified criteria according to Ridge and Cvar. Results: The acquired results showed that after 3 to 6 months there were no changes at none of examined parameters and all the fillings got maximal mark A. 12 months latter, in the two cases with composite filling, the marginal adaptation got the mark $B(607 \%)$. The marginal adaptation at two teeth restored with compo-mers got the mark $B(6.3 \%)$ Postoperative sensitiveness phenomenon, marginal discoloration and secondary caries weren't registered in none of the cases after the observation period of 12 months. Conclusion: For the restoration of non-caries cervical lesions, composite materials with suitable adhesive system and the new generation of compo-mers could be used.

Key words: non-caries cervical lesions, composites, and compo-mers.
Nekarijesne cervikalne sklerotične lezije su česta patologija tvrdih zubnih tkiva i predstavljaju ozbiljan problem u stomatološkoj praksi, ne samo zbog svoje učestalosti, već i zbog etiologije, dijagnoze ali i izbora restaurativne procedure (1).
Non-caries cervical sclerotic lesions are frequent pathology of hard dental tissues and they presents a serious problem in dental practice, not only because of its frequency, but because of aetiology, diagnosis and the choice of restorative procedure. (1) 
Tradicionalno, u nekarijesne lezije se ubrajaju atricije, abrazije i erozije zubnih tkiva. Etiologija ovih kliničkih entiteta je vrlo kompleksna a često je pravi uzrok nepoznat.(2) Iako postoje brojne definicije, nekarijesne cervikalne lezije se najčešće definišu kao spor i «opsežan» gubitak zubne supstance koji rezultuje formiranjem glatkih klinastih defekata duž cementno-gleđne granice. $(1,3)$ Klinički, erozija je pre svega površinski fenomen koji prvo zahvata gleđ, a tek kasnije i dentin dovodeći do njegove skleroze. $(4,5)$ Skleroza dentina je najčešće posledica fiziološkog starenja ali i odgovora dentina na dugotrajne i blage iritacije zuba. $(1,5,6)$ Ovo objašnjava činjenicu da se ove lezije češće javljaju u starijih pacijenata. (1)

Najčešći etiološki faktor u nastanku cervikalnih erozija je ipak hemijska erozija odnosno kiselinsko razlaganje tvrdih zubnih tkiva.(7) Istraživanja su potvrdila da se cervikalne erozije češće javljaju kod osoba koje su izložene kiselinama na radnom mestu (8), kod osoba koje se bave plivanjem kada zubi dolaze u kontakt sa hlorisanom vodom u bazenima (9), odnosno kod osoba koje često konzumiraju kisele napitke (voćni sokovi )(10) ili za oralnu higijenu koriste sredstva koja heliraju kalcijum ili sadrže vitamin C (11). Značajan erozivni potencijal na zubima je uočen i kod osoba sa gastrointestinalnim problemima(12), to jest kod trudnica i alkoholičara (13) zbog čestih povraćanja. Isti problem zapažen je i kod bulimije i anorexiae neurosae.(14)

Međutim, istraživanja poslednjih godina su potvrdila da je stres (savijanje, fleksija ) zuba usled ekscentričnih okluzalnih sila jedan od faktora kojim se može objasniti nastanak cervikalnih lezija.(15,16) Naime, usled neadekvatnog odnosa zuba gornje i donje vilice dolazi do pucanja (prekida) kristalne strukture gleđi i dentina u cervikalnom delu zuba. Usled delovanja hemijskih ili mehaničkih faktora kod ovakvih zuba dolazi do odlamanja čvrstih zubnih struktura. Ovako nastala lezija u literaturi je poznata i kao abfrakcija zuba. $(15,16,17,18)$ Kod starijih pacijenata fleksija zuba tokom mastikacije je često izraženija usled masivnog oštećenja potpornog aparata zuba, čime se takođe objašnjava i povećana incidenca cervikalnih lezija u ovoj populaciji.(19)

Brojne epidemiološke studije ipak kao najčešći uzrok nastanka cervikalnih erozija navode neadekvatno četkanje zuba. Ovo pre svega podrazumeva učestalost, tehniku pranja, dizajn snopova i vlakana četkice, odnosno abrazivnost pasti za zube pri održavanju oralne higijene. $(2,5,20)$

Pravilna i pravovremena klinička dijagnoza kod nekarijesnih cervikalnih lezija je značajna zbog činjenice da se ove lezije mogu javiti u različitim formama, počev od plitkih useka do širokih tanjirastih lezija i velikih klinastih defekata. Lezije se mogu javiti na vestibularnoj, oralnoj ili aproksimalnoj površini zuba $(1,6,7)$ i nije uvek neophodno uraditi restaurativni zahvat. Kada ovakve lezije postanu sklerotične, zub uglavnom postane neosetljiv na nadražaje. Usled prisustva mineralnih depozita koji okludiraju dentin tubule na zubu je značajno smanjen prag nadražaja za bol.(1, 6, 21) Osim toga kod takvih zuba su promenjene
Traditionally, in non-caries lesions there are included attrition, abrasion and erosion of dental tissues. The aetiology of those clinical entities is very complex, and the real cause is often unknown.(2) Although there are numerous definitions, non-caries cervical lesions are most often defined as a slow and "voluminous" loss of tooth substance that resulted in forming smooth wedge-shaped effects along cement enamel borders. $(1,3)$ Clinically, erosion is, above all, surface phenomenon which previously spreads over the enamel and cement, and then dentin leading to its scleroses. $(4,5)$ Dentine scleroses is a result of physiological aging, but it is also the answer of the dentin to long-lasting and mild teeth irritation. $(1,5,6)$ This explains the fact that hose lesions are more frequent at the older patients.(1)

Nevertheless, the most frequent aetiology factor in cervical erosion genesis is chemical etching, that is, the acid discomposed hard dental tissues.(7) The researches confirmed that the cervical erosion are most often at the persons who are exposed to acids on their working place(8), who are competitive swimmers and so used chloride water in the pools (9), or at the persons who consummate sour drinks (jukes)(10) or for the oral hygiene use means which chelate calcium or contents vitamin C.(11) The important erosive potential on teeth is noticed at the persons with gastrointestinal disorders (12), that is, at pregnant women and alcoholics (13) because of the often vomiting. The same problem is noticed at bulimia and anorexia nervosa. (14) However, the researches during the last few years confirmed that the stress (bending, flexing) of the teeth because of the eccentric occlusal forces is one of the factors, which could explain the geneses of cervical lesions. $(15,16)$ Namely, because of the inadequate relation of the teeth from the upper and the lower jaw there comes to cracking (break) of the enamel crystal structure and dentin in cervical part of the tooth. An influence of chemical and mechanical factors leads to the breaking off of the hard dental structures. In this way made lesion is known as dental abfraction in literature. $(15,16,17,18)$ At the older patient, the dental flexion during the mastication is more expressed because of the massive damages of the supporting dental apparatus that explains the increasing incidence of cervical lesions in this population.(19)

The numerous epidemic studies, however, the most often reason for cervical erosions consider inadequate teeth brushing. This means the frequency, the technique, the design of bundles and fibres of a toothbrush, or abrasiveness of toothpaste during the oral hygiene. $(2,5,20)$

The regular and timely set clinical diagnose at non-caries cervical lesions is important because of the fact that those lesions could appear in different forms, starting from shallow cut to the wide sorcery lesions and large wedge- shaped defects. Lesions could appear on vestibular, oral and proximal tooth surface, $(1,6,7)$ and the restorative procedure are not always necessary. When those lesions became sclerotic, the tooth mostly become insensitive to stimulus. Because of the presence of mineral deposit, which occludes tibular, 
njegove optičke karakteristike i on postaje transparentniji.(1)

Ipak, ključni problem u terapijskoj restaurativnoj proceduri je stanje dentina. Za uspeh tretmana neophodno je poznavanje mikromorfoloških karakteristika sklerotičnog dentina, kao osnovnog supstrata za vezu sa restaurativnim materijalom. Literaturni podaci pokazuju da je ovakav dentin promenjen pa je samim tim i otporniji na demineralizaciju. Istraživanja su pokazala da hipermineralizovani površinski sloj dentina sadrži veću gustinu minerala nego sklerotični dentin ispod njega.(22) Terapija cervikalnih lezija je znatno otežana i zbog činjenice da je u restaurativnoj proceduri teško ostvariti adekvatnu adheziju između tvrdih zubnih tkiva i restaurativnih materijala. $(23,24)$ Materijali izbora u zbrinjavanju ovih lezija su kompozitni materijali sa odgovarajućim adhezivim sistemima, glas jonomer cementi ili kombinacija ova dva restaurativna materijala. Međutim, pre restaurativne procedure neophodno je eliminisati loše navike kod pacijenta, sprovesti obuku o pravilnom održavanju oralne higijene i ukazati na značaj pravilne ishrane, odnosno obezbediti adekvatno okluzalno uravnoteženje zuba gornje i donje vilice. $(2,24)$

Cilj ovog rada bio je da se u observacionom periodu od 12 meseci klinički proveri efikasnost restauracija nekarijesnih cervikalnih lezija zuba u zavisnosti od primenjenih materijala za restaurativne ispune.

\section{Materijal i metod}

Klinička ispitivanja su obuhvatila 62 zuba različitih morfoloških grupa kod pacijenata oba pola i rzličite starosti. Kod svih zuba uključenih u analizu, postavljena je dijagnoza nekarijesnih cervikalnih lezija a pacijenti su pokazali spremnost da dolaze na kontrolne preglede odnosno bili su obučeni kako da održavaju oralnu higijenu (tabela 1). dentin the threshold level of pain on the tooth is decreasing. $(1,6,21)$ Besides that the optical characteristics of those teeth are changed and they became more transparent.(1)

Nevertheless, the main problem in therapeutic restorative procedure is dentine condition. For the successful treatment the knowledge of morphological characteristics of sclerotic dentin is needed, as a basic substrate for the bondage with restorative material. The literature data show that this kind of dentin is changed and so it is resistible to demineralisation. The researches show that hyper mineralised surface dentine layer consists larger mineral thickness then the sclerotic one underneath.(22) The cervical lesions therapy is considerably hardened also for the fact that in the restorative procedure it is hard to achieve adequate adhesion between the hard dental tissue and restorative materials. $(23,24)$ Material chosen in taken care of those lesions are composite materials with suitable adhesive systems, glass ionomer cements or a combination of those two. However before the restorative procedure it is necessary to eliminate patient's bad habits, to provide the training about the correct oral hygiene and point to the importance of regular nourishment, in other words, to provide adequate occlusal balance of upper and lower jaw teeth. $(2,24)$

The aim of this work was to, in observational period of 12 months, clinically check the restoration efficiency of non-caries cervical sclerotic teeth lesions, in dependence to applied material for restorative fillings.

\section{Material and method}

The clinical research covered 62 teeth of different morphology group at the patients of both gender and of different age. The whole teeth included in the analyses were diagnosed non-caries cervical lesions and the patients show readiness to come to control checkups, that is they were trained how to keep the oral hygiene (table 1).

Tabela 1. Distribucija pacijenata po polu i grupama zuba

Table 1. Distribution of patients by gender and teeth groups

\begin{tabular}{|l|c|c|c|c|c|c|c|c|c|c|}
\hline \multirow{2}{*}{ materijal } & \multicolumn{2}{|c|}{ POL } & \multicolumn{5}{|c|}{ GORNJA VILICA } & \multicolumn{5}{c|}{ DONJA VILICA } \\
\cline { 2 - 12 } & $\mathrm{M}$ & Z & sekutići & očnjaci & premolari & molari & sekutići & očnjaaci & premolari & molari \\
\hline \multirow{2}{*}{ kompozit } & 18 & 12 & 6 & 3 & 5 & 3 & 3 & 4 & 4 & 2 \\
\hline GJC & 15 & 17 & 7 & 3 & 6 & 3 & 3 & 3 & 6 & 1 \\
\hline \multirow{2}{*}{ ukupno } & 33 & 29 & 13 & 6 & 11 & 6 & 6 & 7 & 10 & 3 \\
\hline
\end{tabular}


Posle detaljne stomatološke anamneze i kliničkog pregleda, kod svih pacijenata je kavitet mehanički očiščen odgovarajućom četkicom i pastom, obezbeđeno je suvo polje rada i bez prethodne preparacije urađena rekonstrukcija lezije.

Restauracija gingivalnih defekata je urađena kompozitnim adhezivnim sistemom SINGLE BOND/Valux Plus (3M) (30 zuba) i kompomerom DYRACT AP (DENTSPLY) (32 zuba).

Kod kaviteta restaurisanih kompozitnim materijalom SINGLE BOND/Valux Plus primenjena je adhezivna tehnika totalnog nagrizanja gleđi $35 \%$ rastvorom fosforne kiseline (30 sek) i dentina (15 sek). Potom je urađena aplikacija adhezivnog sredstva (SINGLE BOND) a kompozitni materijal je unošen u kavitet slojevitom tehnikom. Svaki sloj je pojedinačno polimerizovan u trajanju od 40 sek. Definitivna obrada ispuna urađena je $u$ istoj poseti primenom Soft-Lex diskova i gumica različitih oblika i finoće zrna.

Kod cervikalnih lezija restaurisanih kompomerom DYRACT AP, prajmer /adheziv (PRIME/ADHESIVE) je aplikovan na gleđ i dentin tokom 30 sek i potom polimerizovan svetlom u trajanju od 10 sek. Na isti način je aplikovan i drugi sloj prajmera a zatim je lezija ispunjena materijalom u dva sloja. Svaki sloj je posebno polimerizovan u trajanju od 40 sek. Definitivna obrada restauracije urađena je $\mathrm{u}$ istoj poseti primenom Soft -Lex diskova i gumica različitog oblika i finoće zrna.

Ispuni su procenjivani na kontrolnim pregledima posle 3, 6 i 12 meseci. Kontrolni pregledi su obavljani inspekcijom pomoću stomatološke sonde i ogledalca pod veštačkim osvetljenjem a dobijeni nalazi unošeni su u karton za svakog ispitanika ponaosob.

Vrednovanje dobijenih rezultata urađeno je primenom modifikovanih kriterijuma za evaluaciju po Ridgeu i Cvar-u 25, a procenjivano je stanje površine ispuna, anatomska forma, ivična diskoloracija, ivična adaptacija, pojava sekundarnog karijesa i postoperativna osetljivost zuba. U analizi ocena A je označavala najbolji kvalitet, ocena $\mathrm{B}$ početne promene, a ocena $\mathrm{C}$ nezadovoljavajući kvalitet ispuna.

\section{Rezultati}

Dobijeni rezultati kliničkih ispitivanja prikazani su u tabeli 2. i fotografijama 1-2.

$\mathrm{Na}$ kontrolnim pregledima posle 3 i 6 meseci nisu uočene promene na restaurisanim lezijama ni kod jednog od ispitivanog parametra, odnosno svi ispuni sa kompozitnim materijalima i oni sa kompomerima su ocenjeni maksimalnom ocenom $\mathrm{A}$.

Posle 12 meseci registrovane su promene u po dva slučaja restaurisanih kompozitnim materijalima odnosno kompomerima. Kada je u pitanju ivična adaptacija, 6,7 \%
After more detailed dental anamnesis and clinical check-up, all the patients whose cavity was mechanically cleaned with appropriate toothbrush and toothpaste, the dry work field was provided and without previous preparation the lesion reconstruction was done.

The gingival defects restoration was done with composite adhesive system SINGLE BOND/Valux plus (3M) (30 teeth) and with compo-mer DYRACT AP (DENTSPLY) (32 teeth).

At the cavities reconstructed with composite material SINGLE BOND/Valux plus there was applied an adhesive technique of total enamel erosion with $35 \%$ phosphorus acid $(30 \mathrm{sec})$ and dentine etching $(15 \mathrm{sec})$. After that the application of adhesives (SINGLE BOND), a composite material was added in a cavity in a layered technique. Each layer was polymerised in duration of $40 \mathrm{sec}$. The definite treatment of a filling was done at the same time applying the Soft-Lex discs and rubbers of different grains kind and delicacy.

At cervical lesions restored with DYRACT AP compo-mer, prime/adhesive (PRIME/ADHESIVE) the enamel and dentin were applied for $30 \mathrm{sec}$ and after that polymerised with light during $10 \mathrm{sec}$. The same way was used to apply the second layer of primer, and after that the lesion was filled with two-layers material. Each layer was separately polymerised during $40 \mathrm{sec}$. The definite restoration treatment was done the same time applying the SoftLex discs and rubbers of different grains kind and delicacy.

The fillings were estimated on the control check-ups after 3,6 and 12 months. The control check-ups were done in an inspection with the help of dentist sound and mirror under the artificial light, and the findings received were put in a card of each patient.

The evaluation of the findings was done by application of modified criteria for the evaluation according to Ridge \& Cvar 25, and there were evaluated: the state of the filling surface, anatomic form, marginal discolouration, marginal adaptation, secondary caries appearance and post-operative tooth sensitivity. In those analyses the best quality was marked as A, B marked the initial changes, and $\mathrm{C}$ unsatisfying filling quality.

\section{Results}

The received results are shown in the table 2 and the photographs 1 and 2.

On the control check-ups after 3 and 6 months the changes on restored lesions were noticed at none of the tested parameters, that is, all the fillings with composite materials and those with compo-mers were marked with maximal A.

12 months later the changes were registered in two cases restored with composite materials and in two cases restored with compo-mers. Regarding the marginal adapta- 
ispuna restaurisanih kompozitnim materijalima je ocenjeno ocenom B, kao i 6,3 \% ispuna restaurisanih kompomerima.

Stanje površine ispuna $\mathrm{u}$ jednom slučaju je ocenjeno ocenom B kod lezija ispunjenih kompomerom (3,2\%), kao $\mathrm{i}$ anatomska forma kod lezija zbrinutih kompozitnim ispunima $(3,5)$.

U ovim istraživanjima pojava postoperativne osetljivosti, ivične diskoloracije i sekundarnog karijesa nije zapažena ni u jednom slučaju posle observacionog perioda od 12 meseci. tion, $6.7 \%$ of fillings restored with composite materials was marked B, same as $6.3 \%$ fillings restored with compo-mers.

The state of the filling surface in one case was marked B at lesions filled with compo-mer (3.2\%), same as the form, at lesions restored with composite fillings $(3.5 \%)$.

In those researches the appearance of marginal discolouration, secondary caries appearance and post-operative tooth sensitivity was noticed in none of the cases after the observational period of 12 months.

Tabela 2. Rezultati kliničke analize restauracija nekarijesnih cervikalnih lezija

Table 2. Clinical analysis of restorations of noncarious cervical lesions - results

\begin{tabular}{|c|c|c|c|c|c|c|c|c|c|c|c|c|c|}
\hline \multirow{3}{*}{ parametri } & \multirow{3}{*}{ ocena } & \multicolumn{4}{|c|}{$\begin{array}{l}\text { I kontrola } \\
3 \text { meseca }\end{array}$} & \multicolumn{4}{|c|}{$\begin{array}{l}\text { II kontrola } \\
6 \text { meseci }\end{array}$} & \multicolumn{4}{|c|}{$\begin{array}{c}\text { III kontrola } \\
12 \text { meseci }\end{array}$} \\
\hline & & \multicolumn{2}{|c|}{ kompozit } & \multicolumn{2}{|c|}{ GJC } & \multicolumn{2}{|c|}{ kompozit } & \multicolumn{2}{|c|}{ GJC } & \multicolumn{2}{|c|}{ kompozit } & \multicolumn{2}{|c|}{ GJC } \\
\hline & & $\mathrm{N}$ & $\%$ & $\mathrm{~N}$ & $\%$ & $\mathrm{~N}$ & $\%$ & $\mathrm{~N}$ & $\%$ & $\mathrm{~N}$ & $\%$ & $\mathrm{~N}$ & $\%$ \\
\hline Stanje površine ispuna & $\begin{array}{l}\mathrm{A} \\
\mathrm{B} \\
\mathrm{C}\end{array}$ & 30 & 100 & 32 & 100 & 30 & 100 & 32 & 100 & 30 & 100 & $\begin{array}{c}31 \\
1\end{array}$ & $\begin{array}{c}96,8 \\
3,2\end{array}$ \\
\hline Anatomska forma & $\begin{array}{l}\text { A } \\
\text { B } \\
\text { C }\end{array}$ & 30 & 100 & 32 & 100 & 30 & 100 & 32 & 100 & $\begin{array}{c}29 \\
1\end{array}$ & $\begin{array}{c}96,6 \\
3.5\end{array}$ & 32 & 100 \\
\hline Ivična diskoloracija & $\begin{array}{l}\mathrm{A} \\
\mathrm{B} \\
\mathrm{C}\end{array}$ & 30 & 100 & 32 & 100 & 30 & 100 & 32 & 100 & 30 & 100 & 32 & 100 \\
\hline Ivična adaptacija & $\begin{array}{l}\text { A } \\
\text { B } \\
\text { C }\end{array}$ & 30 & 100 & 32 & 100 & 30 & 100 & 32 & 100 & $\begin{array}{c}28 \\
2\end{array}$ & $\begin{array}{c}93,3 \\
6,7\end{array}$ & $\begin{array}{c}30 \\
2\end{array}$ & $\begin{array}{c}93,7 \\
6,3\end{array}$ \\
\hline Sekundarni karijes & $\begin{array}{l}\text { A } \\
\text { B } \\
\text { C }\end{array}$ & 30 & 100 & 32 & 100 & 30 & 100 & 32 & 100 & 30 & 100 & 32 & 100 \\
\hline Postoperacijska osetljivost & $\begin{array}{l}\mathrm{A} \\
\mathrm{B} \\
\mathrm{C}\end{array}$ & 30 & 100 & 32 & 100 & 30 & 100 & 32 & 100 & 30 & 100 & 32 & 100 \\
\hline
\end{tabular}

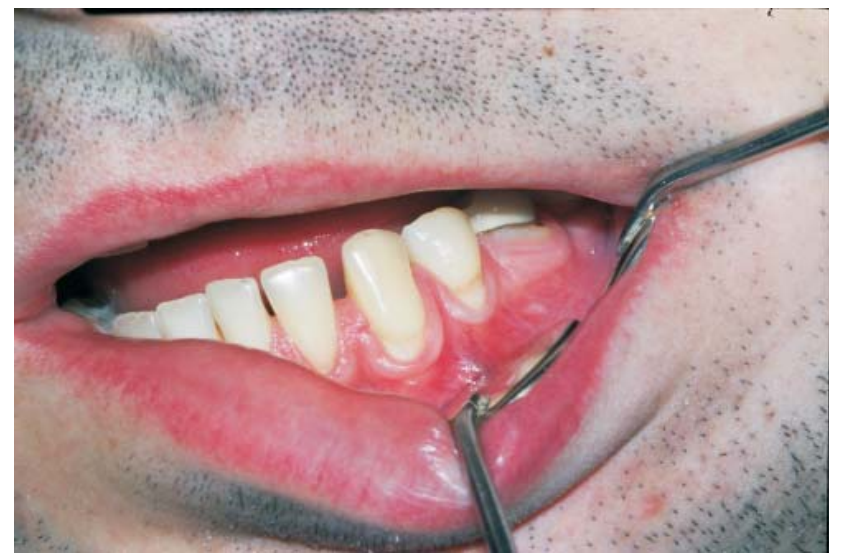

A

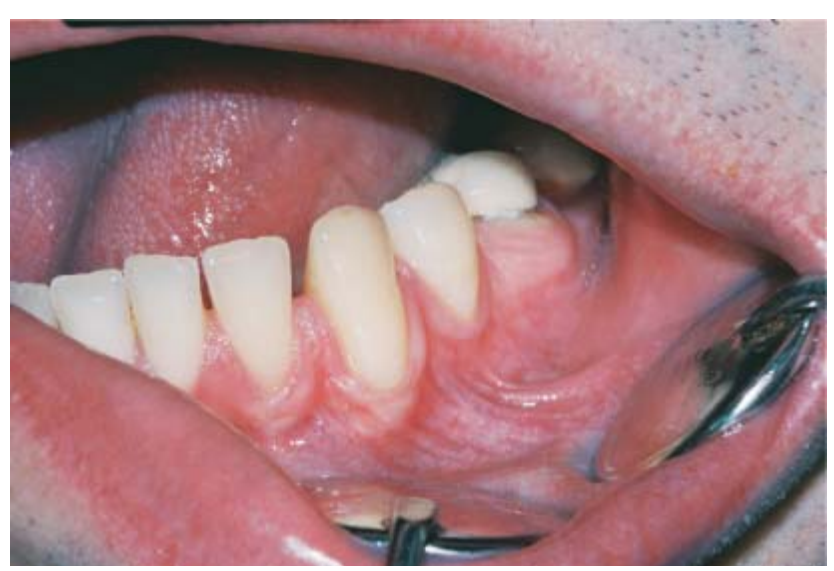

B

Slika 1. Nekarijesna cervikalna lezija na mandibularnom očnjaku i prvom premolaru sa leve strane restaurisana kompozitnim materijalom Valux Plus/Single bond A-pre intervencije B-12 meseci nakon restauracije

Figure 1. Non-carious cervical lesion on mandible left canine and first premolar restored with composite material Valux Plus/Single bond $A$ - before treatment $\quad B-12$ months after treatment 

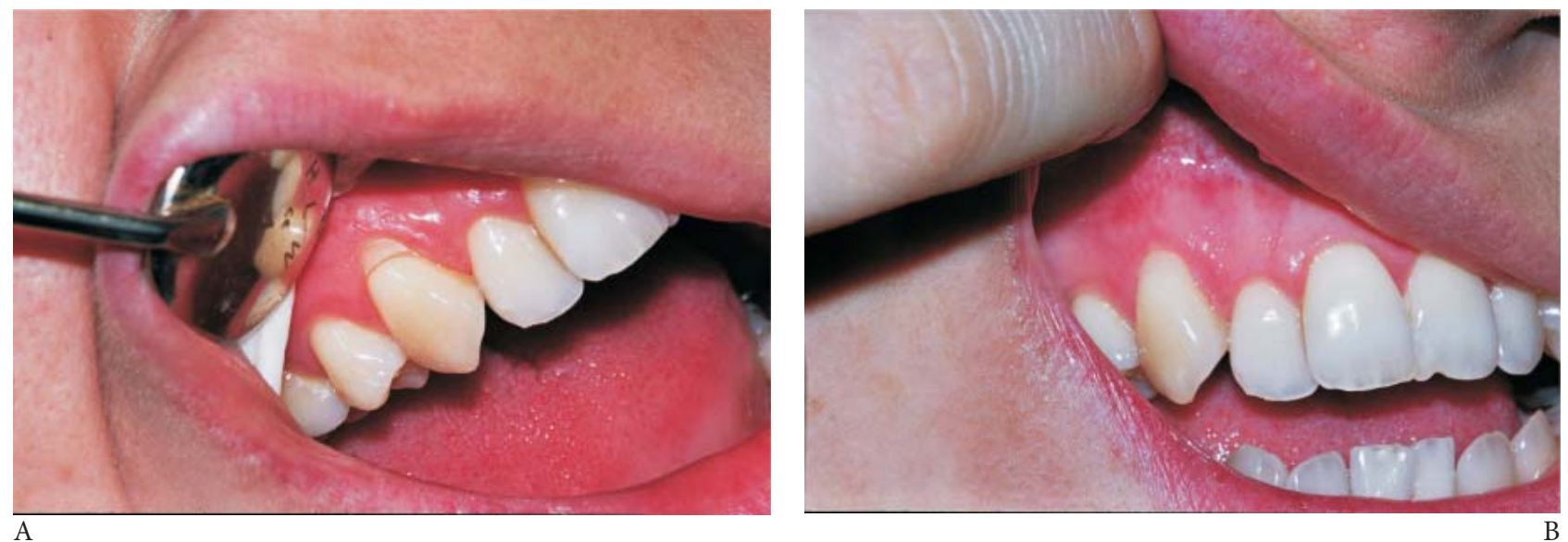

Slika 2. Nekarijesna cervikalna lezija na maksilarnom očnjaku sa desne strane restaurisana kompomerom Dyrect AP

$A$-pre intervencije $B-12$ meseci nakon restauracije

Figure 2. Non-carious cervical lesion on maxillary right canine restored with compo-mer Dyrect AP

$A$-before treatment $\quad B$ - 12 months after treatment

\section{Diskusija}

Terapija nekarijesnih cervikalnih lezija je značajan problem u restaurativnoj stomatologiji iz više razloga. To pre svega uključuje nejasnu etiologiju, česte recidive ali i značajne probleme u retenciji, odnosno adheziji materijala za sklerotično promenjenu mikrostrukturu dentina.(1,23,26,27) Pojedine kliničke studije posebno ukazuju na povećanu stopu neuspeha kod starijih pacijenata,(27) a druge kao problem navode stepen skleroze, fleksiju zuba, koncentraciju kiseline za nagrizanje, vreme aplikacije, odnosno osetljivost restaurativnih tehnika. $(26,27,30)$

U ovoj kliničkoj studiji najveći broj kompozitnih $\mathrm{i}$ ispuna urađenih kompomerima je posle 12 meseci ocenjen najvišom ocenom. Naime, ni u jednom slučaju nije uočena pojava ivične diskoloracije, postoperativne osetljivosti, odnosno pojava sekundarnog karijesa. Kratak period opservacije, odnosno adekvatno realizovana oralna higijena pacijenata je verovatno razlog što je većina ispitivanih parametara ocenjena najvišom ocenom. Neadekvatna ivična adaptacija zapažena u slučajevima gde je cervikalna lezija restaurisana kompozitnim materijalima i kompomerima mogla bi biti posledica neadekvatne adhezivne veze materijala, ali ne isključuje ni terapijske greške u osetljivoj terapijskoj proceduri. Savremena stomatologija vezu kompozitnih restaurativnih materijala za sklerotičan dentin objašnjava dobrom mikromehaničkom vezom odnosno infiltracijom smole (produžetaka) u tubularni i intertubularni dentin. $(1,19)$ Međutim, ova smolom ojačana zona dentina ili hibridni sloj je znatno tanja kod sklerotičnog dentina u poređenju sa normalanim dentinom. $(1,28,29)$

U ovoj kliničkoj studiji restauracije nekarijesnih cervikalnih lezija kompozitnim materijalima izvedena je tehnikom totalnog nagrizanja gleđi i dentina fosfornom kiselinom i primenom samonagrizajućih prajmera kod kompomera. Ovo objašnjava da se time obezbeđuje kvalitetnija pripre-

\section{Discussion}

The therapy of non-caries cervical lesions is an important problem in restorative dentistry for a number of reasons. Above all, it includes ambiguous aetiology, frequent relapses but without prominent problems in retention, that is material adhesion for the sclerotic changed dental microstructure. $(1,23,26,27)$ Some of the clinical pictures are showing increased failure rate at the older patients,(27) and the other problems are the sclerosis level, teeth flexion, etch acid concentration, application time, that is the sensitivity of the restoring techniques. $(26,27,30)$

In this clinical study, the largest number of composite fillings and fillings done with compo-mers, was marked with the highest marks after 12 months. Namely, in none of the cases were noticed marginal discolouration, secondary caries and post-operative sensitivity. The short period of observation, that is, the adequately realised patients' oral hygiene is probably the reason for the high marks at most of tested parameters. Inadequate marginal adaptation noticed at the cases where cervical lesion had been restored with composite materials and compo-mers, could be the consequence of inadequate adhesive material bonding, bit it doesn't exclude therapy mistakes in sensitive therapy procedure. Contemporary dentistry explains the bonding of composite restorative materials for sclerotic dentine with good mechanical bonding more exactly, the resin infiltration into tubular and inter tubular dentin. $(1,19)$ However, this resin fortified dentine zone or hybrid layer is significantly smaller in the sclerotic dentin then in the normal one. $(1,28,29)$

In this clinical study, the restoration of non-caries cervical sclerotic lesions with composite materials was done with the technique of total enamel and dentine etch with phosphorus acid and applying self-etching primers at compo-mers. This is the explanation for providing the 
ma sklerotičnog dentina a samim tim ostvaruje i bolja veza posle totalnog kiselinskog nagrizanja. Van Dijken (30), ističe da sklerotičnom dentinu posle kiselinskog nagrizanja često nedostaju funkcionalne fibrile i sunđerasti organski matriks koji je neophodan za intertubularnu difuziju smole i nastanak hibridnog sloja. Zato se adhezivna veza za sklerotičan dentin tumači i objašnjava vrlo slično kao veza koju ostvaruju materijali sa gleđi. Ova veza se zasniva pre svega na kreiranju visokoenergetske i hrapave površine za vezu a ne na impregnaciji smolom dekalcifikovanog dentina.(1,30,31) Time se mogu objasniti i dobri rezultati u ovim kliničkim istaživanjima ostvareni primenom kompomera za ispune.

Klinički nalazi iz literature su takođe vrlo različiti. Uglavnom se slažu u činjenici da je teško ostvariti kvalitetnu adhezivnu vezu restaurativnih materijala za sklerotičan dentin kod starijih osoba.(30,32) Glavni razlog adhezivnog neuspeha je promenjena mikrostruktura slerotičnog dentina. $(26,27,32)$

Klinička ispitivanja Van Dijkena (30) u jednoj trogodišnjoj studiji su potvrdila klinički prihvatljive rezultate sa adhezivima u tri koraka (kiselina, prajmer, bond) i smolom modifikovanim glas jonomer cementima. Nešto više neuspeha registrovano je kod samonagrizajućih adheziva u jednoj boci. Nalazi Van Merbeka i saradnika u obimnoj jednogodišnjoj studiji su, međutim, ukazali na neuspeh u terapiji cervikalnih lezija. Naime, nijedan od testiranih adheziva in vivo nije obezbedio kvalitetno rubno zatvaranje i u najvećem broju restaurisanih lezija je zapažena diskoloracija ivica ispuna.(27)

Literaturni nalazi takođe ukazuju da kiselost kondicionera (kiseline ili prajmera) značajno utiče na kvalitet veze. Naime, kondicioneri čiji je $\mathrm{pH}=1,6$ dovodi do sekundarne demineralizacije dentina i time do dublje penetracije smole u demineralizovanu povšinu dentina i tubule. Dublja penetracija može biti i posledica acetonskog rastvarača koji smanjuje viskoznost smole i olakšava njeno prodiranje u demineralizovan dentin.(33)

Značajan faktor za uspešnu restaurativnu terapiju cervikalnih nekarijesnih lezija je pre svega pravilno sprovedena restaurativna procedura. Adekvatno ostvareno okluzalno uravnoteženje i smanjena fleksija zuba tokom mastikacije, odnosno pravilno održavanje oralne higijene i dobro odabrana četkica, pasta, i tehnika pranja zuba su takođe nezaobilazni faktori kvaliteta i dugotrajnosti ispuna nekarijesnih cervikalnih lezija.

\section{Zaključak}

$\mathrm{Na}$ osnovu sprovedenih kliničkih istraživanja može se zaključiti da se zbrinjavanje nekarijesnih cervikalnih lezija može na zadovoljavajući način realizovati i kompozitnim materijalima i kompomerima. Za kvalitet i dugotrajnost ispuna neophodan je pravilan izbor materijala i pravilno sprovedena restaurativna procedura i adekvatna higijena usta i zuba. more qualitative sclerotic dentine preparation, and with that it is achieved better bonding after total acid etching. Van Dijken (30) emphasizes, that the sclerotic dentin after the acid etching often lacks functional fibrils and sponged organic matrix that is necessary for inter-tubular resin diffusion and the origination of hybrid layer. That is why the adhesive bond for sclerotic dentine is explained similarly to a bond established by materials and enamel. This bond is based, above all on creating highly energetic and rough surface for bonding, not on resin impregnation of decalcified dentin.(1,30,31) That is the way to explain the good results in those clinical researches that were made by using compo-mers for fillings.

The clinical findings in literature are different, too. They mainly agreed in the fact that it is very hard to achieve the quality bond of restorative materials for sclerotic dentin at older persons. $(30,32)$ The main reasons for the adhesive failure is changed microstructure of dentin. $(26,27,32)$

The clinical researches of Van Dijken (30) in three years long study confirmed clinically acceptable result with adhesive in three steps (acid, primer, bond) and a resin, modified with glass ionomer cements. A little bit more unsuccessful try was registered with self-etching adhesives in one bottle. The findings of Van Meerbeek and associates in a voluminous one-year study, however, showed the failure in cervical lesions therapy. Namely, none of tested adhesives in vivo didn't provide qualitative marginal sealing and a discoloration of the fillings' edges was noticed in most of the restored lesions.(27)

The literature findings also point out that the conditioner acidity (acid or primer) importantly influence on the quality of the bonding. The conditioner which has $\mathrm{pH}=1.6$ leads to secondary dentine demineralisation and with it to deeper resin penetration in demineralised dentin and tubule surface. Deeper penetration could be the consequence of acetone solvent, which reduces resin viscosity and facilitates its penetration into demineralised dentin.(33)

The important factor for the successful restorative therapy of non-caries cervical lesions is, above all, correctly executed restorative procedure. Adequately accomplished occlusal balance and reduced flexion of the teeth during mastication, in other words, regular oral hygiene and well chosen toothbrush and toothpaste, and washing technique, are also inevitable factors for the quality and long-lasting fillings of non-caries cervical lesions.

\section{Conclusion}

Based on the administered clinical researches, it could be concluded that, the treatment of non-caries cervical lesions could be realised in satisfied way with composite materials and compo-mers. For the quality and longlasting fillings it is necessary to choose the right materials and to conduct correctly the restorative procedure and adequate oral hygiene. 


\section{Literatura / References}

1. Nour El-din AK, Miller BH, Griggs JA. Resin bonding to sklerotic, noncarious, cervical lesions, Quintessence Int 2004, 35: 529-540

2. Litonjua LA, Andreana S, Cohen RE. Tooth wear: attrition, erosion and abrasion, Quintessence Int 2003, 34: 435-446

3. Imfeld T. Dental erosion, definition, classification and links. Eur J Oral Sci 1996; 104: 151-155

4. Moss SJ. Dental erosion. Int Dent J,1998, 48: 529-539

5. Hattab FN, Yassin OM. Etiology and dijagnosis of tooth wear: A literature review and presentation of selected cases. Int J Prosthodont 2000; 13:101-107

6. Hollinger JO, Moore EM. Hard tissue loss at the cementoenamel junction: a clinical study JNJ Dent Assoc 1979; 50 : 27-31

7. Leviteh LC, Bader JD, Shugars DA, Heymann HO. Noncarious cervical lesions, J Dent 1994, 22: 195-207

8. Ten Bruggen Cate HJ. Dental erosion in industry, BR J Ind Med 1968, 28: 249-266

9. Centerwal BS, Armstrong CW, Funkhouser LS, Elzay RP. Erosion of dental enamel among competitive swimmers at a gas-chlorinated swimming pool. Am J Epidemiol 1986, 123: 641-647

10. Poynter ME, Wright PS. Tooth wear and some factors influencing its severity. Restorative Dent 1990; 6: 8-11

11. Jarvinen VK, Rytomaa II, Heinonen O. Risk faktors in dental erosion. J Dent Res 1991; 70: 942-947

12. Jarvinen VK, Meurman JH, Hyvarinen H, Rytoma/, Murtomaa H. Dental erosion and upper gastrointestinal disorders, Oral Surg Oral Med Oral Pathol 1988; 65: 298-303

13. Smith BG, Robb ND. Dental eriosion in patients with chronic alcolohilsm $J$ Dent 1989; 17: 219-221

14. Knewitz JL, Drisko CL. Anorexia nervosa and bulimia: A review. Compendium 1988; 9: 244-247

15. Burke FJ, Whitehead SA, Mc Caughey AD. Contemporary concepts in patogenesis of the Class $\mathrm{V}$ non-carious lesion Dent Update 1995; 22: 28-32

16. Rees JS. The role of cuspal flexure in the development of abfraction lesions: A finite element study, Eur J Oral Sci, 1998; 106: 1028-1032

17. Grippo JO. Abfractions: A new clasification of hard tissue lesions of teeth. J Estet Dent 1991; 3: 14-19

18. Xhonga FA. Bruxism and its effect on the teeth. J Oral Rehabil, 1977; 4: 65-76

\section{Autor odgovoran za korespondenciju}

Slavoljub Živković

Klinika za Bolesti zuba

Stomatološki fakultet Beograd

Rankeova 4, 11000 Beograd

Tel. $2435722 / 222$
19. Harnirattisai C, Inokoshi S, Shimada Y, Hosoda H. Adhesive interface between resin and etched dentin of cervical erosion /abrasion lesions. Oper Dent 1993; 18: 138-143

20. Bishop K, Kelleher M, Briggs P, Joshi R. Wear now? An update on the etiology of wear. Quintessence Int 1997; 28: 305-313

21. Yoshiyama M, Noiri Y, Ozaki K, Uchida A, Ishikawa Y, Ishida H. Transmission elektron microscopic characterisation of hipersenzitive human radicular dentin J Dent Res 1990; 69:1293-1297

22. Schupbach P, Lutz F, Guggenheim B. Human root caries: Histopathology of arrested lesions. Caries Res 1992;26: 153-164

23. Živković. Quality assesment of marginal sealing using 7 dentin adhesive systems, Quintessence Int, 2000; 31: 423-429

24. Coleman TA, Grippo JO, Kinderknecht KE. Cervical dentin hipersensitivity Part II: Association with abfractive lesions, Quintessence Int 2000; 31: 466-473

25. Stanford GW, Ryge G. Recomended format for protocol for clinical research program. Clinical comparison of several anterior and posterior materials. Int Dent J, 1977; 27: 46-59

26. Duke ES, Robbins JW, Snyder DS, Clinical evaluation of a dentinal adhesive sistem : three years results. Quintessence Int 1991; 22: 889-895

27. Van Meerbeek B, Peumans M, Gladys S, Braem M, Lambrechts P, Vanherle G. Three year effectiveness of four total etch dentinal adhesive systems in cervical lesions. Quintessence Int 1996; 27: 775-784

28. Kwong SM, Tay FR, Yip HK, Kei LH, Pashley DH. An ultrastructural study of the aplication of dentine adhesives to acid- conditioned sclerotic dentine. J Dent 2000; 28: 515-528

29. Yoshyama M, Carvalho RM, Sano H, Horner JA, Brever PD, Pashley DH. Regional bond strengths of resins to human root dentine. J Dent 1996; 24: 435-442

30. Van Dijken JW. Clinical evaluation of three adhesive systems in class V non carious lesions. Dent Mater 2000; 16: 285-291

31. Tay FR, Kwong SM, Itthagarun A et al. Bonding of a self etching primer to non- carious cervical sclerotic dentin : Interfacial ultrastructure and microtensive bond strength evaluation. $J$ Adhes Dent 2000; 2: 9-28

32. Heymann HO, Sturdevant JR, Bayne S, Wilder AD, Sluer TB, Brunson WD. Examining tooth flexure effects on cervical restorations: a two years clinical study. J Am Dent Assoc 1991; 122: 41-47

33. Prati C, Chersoni S, Monriorgi R, Montanari G, Pashley DH. Thickness and morphology of resin- infiltrated dentin layer in young, old and sclerotic dentin. Oper Dent 1999; 24: 66-72

\section{Address for correspondence}

Slavoljub Živković

Dept. of Conservative Dentistry and Endodontics

School of Dentistry, Belgrade

Rankeova 4, 11000 Belgrade, Serbia and Montenegro

Tel. +381112435 722/222 